\title{
The rare intracellular RET mutation p.Ser891 Ala in an apparently sporadic medullary thyroid carcinoma: a case report and review of the literature
}

\author{
Rara mutação intracelular p.Ser891Ala do RET em \\ carcinoma medular de tireoide aparentemente \\ esporádico: relato de caso e revisão da literatura
}

${ }^{1}$ Thyroid Section, Endocrine Division, Hospital de Clínicas de Porto Alegre, Universidade Federal do Rio Grande do Sul (UFRGS), Porto Alegre, RS, Brazil

Carla Brauner Blom', Lucieli Ceolin', Mirian Romitti', Débora Siqueira', Ana Luiza Maia'

\section{SUMMARY}

Medullary thyroid carcinoma (MTC) is a malignant tumor originating from parafollicular C-cells and accounts for $4-10 \%$ of all thyroid carcinomas. MTC develops in either sporadic $(75 \%)$ or hereditary form (25\%). Mutations in the RET proto-oncogene are responsible for hereditary MTC and the rate of heritable disease among apparently sporadic MTC (sMTC) cases varies from 6 to $15 \%$. RET genetic testing is now considered fundamental in MTC management but the extent of the molecular analysis required to exclude inherited disease is still controversial. While the screening of all known mutation loci is recommended by some authors, the high costs associated with a full analysis should be also taken into consideration. Here, we illustrate and discuss this controversial issue by reporting a patient who present all characteristic features of SMTC, and in whom a standard genetic analysis by restriction enzyme restriction excluded hereditary disease. Nevertheless, an extensive molecular analysis that included all codons was prompted by the diagnosis of thyroid neoplasm in a patient's sister, and identified the rare intracellular RET p.Ser891Ala mutation. Arq Bras Endocrinol Metab. 2012;56(8):586-91

\section{SUMÁRIO}

Correspondence to:

Ana Luiza Maia

Serviço de Endocrinologia,

Hospital de Clínicas de Porto Alegre Rua Ramiro Barcelos, 2350

90035-003 - Porto Alegre, RS, Brazil almaia@ufrgs.br

Received on Aug/4/2012 Accepted on Oct/30/2012

\begin{abstract}
$\mathrm{O}$ carcinoma medular de tireoide (CMT) é um tumor maligno originado das células $\mathrm{C}$ parafoliculares e corresponde a $4-10 \%$ de todos os carcinomas de tireoide. O CMT se desenvolve ou de forma esporádica (75\%) ou hereditária (25\%). As mutações no proto-oncogene $R E T$ são responsáveis pelo $C M T$ hereditário, e a ocorrência de doença hereditária entre casos aparentemente esporádicos de CMT varia de 6 a 15\%. A avaliação genética do RET é considerada fundamental no manejo do CMT, mas a extensão de análise molecular necessária para se excluir a doença hereditária ainda é controversa. Embora a avaliação de todos os loci de mutação conhecidos seja recomendada por alguns autores, os altos custos associados com a análise completa devem ser considerados. Neste relato, ilustramos e discutimos esse assunto controverso por meio do caso de um paciente que apresentou todas as características clássicas de CMT esporádico e no qual a análise genética por restrição enzimática excluiu a doença hereditária. No entanto, devido ao diagnóstico de uma neoplasia de tireoide em uma irmã do paciente, foi indicada uma análise molecular mais extensa que identificou a rara mutação intracelular p.Ser891Ala no proto-oncogene RET. Arq Bras Endocrinol Metab. 2012;56(8):586-91
\end{abstract}

\section{INTRODUCTION}

$\mathrm{M}$ edullary thyroid cancer (MTC) is a neuroendocrine tumor of the calcitonin-producing para- follicular C-cells of the thyroid gland, accounting for $4-10 \%$ of all thyroid carcinomas (1). MTC is mainly sporadic (70-80\%), but may also be part of an inherited 
disorder transmitted as an autosomal dominant trait with $100 \%$ penetrance, referred as multiple endocrine neoplasia type 2 (MEN 2). The MEN 2 syndrome is classified into three distinct clinical subtypes: MEN type 2A (MEN 2A), characterized by the presence of MTC, pheocromocytoma (PHEO), and hyperparathyroidism (HPT); MEN type 2B (MEN 2B), that includes MTC, PHEO, ganglioneuromatosis, and marfanoid habitus, and familial MTC (FMTC), characterized by MTC as the only feature of the disease (2). Germline mutations in the RET proto-oncogene (REarranged during Transfection) are responsible for hereditary MTC and affect approximately $\mathrm{l}$ in every 30,000 individuals (3).

Clinical MTC is usually presented as a thyroid nodule or mass. Palpable cervical lymph nodes are present in $50-75 \%$ of the cases, while distant metastases are detectable in about $20 \%$ of the patients at diagnosis $(4,5)$. The presence of metastatic disease has been associated with a lower chance of cure even in children and young adults (6).

RET molecular analysis is essential in MTC management, since early diagnosis improves prognosis and allows adequate genetic counseling (6-8). Nevertheless, the extent of the molecular analysis required to exclude germline mutations is still controversial. The percentage of cases of heritable disease among apparently sporadic medullary thyroid carcinoma (sMTC) cases accounts for 6-15\%, mainly located in non-cysteine codons, and awareness of familial clustering should prompt systematic family screening $(9,10)$.

We describe here a patient with apparently sMTC in whom a standard genetic analysis excluded hereditary disease. After a first-degree relative presented a thyroid adenoma, an extended molecular sequence analysis identified a rare mutation in exon 15 , and, therefore, heritable disease.

\section{PATIENT AND METHODS}

\section{Case report}

A 53-year-old male was referred to our Institution for genetic evaluation and follow-up due to a diagnosis of MTC. Clinical investigation for a thyroid nodule started 1 year before. Laboratorial evaluation disclosed serum calcitonin levels of $181 \mathrm{pg} / \mathrm{mL}$ (Immulite 2000, Diagnostic Products Corporation, Los Angeles, CA, USA; reference value (VR) male: $12.0 \mathrm{pg} / \mathrm{mL}$ and female: $6.0 \mathrm{pg} / \mathrm{mL}$ ). Cervical examination revealed a palpable and not enlarged thyroid, with a palpable hard nodule. Thyroid ultrasonography (US) showed a $2.0 \mathrm{~cm}$ solid, heterogeneous, and irregular nodule, with no evidence of lymph node involvement. Fine-needle aspiration biopsy (FNAB) was positive for MTC. Contrast-enhanced computed tomography (CT) scan of the thorax and abdomen were negative for metastases. The patient underwent total thyroidectomy without cervical neck dissection. The anatomopathological exam revealed a unique solid nodule measuring $2.2 \mathrm{~cm}$. Histopathological examination showed cells displaying amphophilic cytoplasm on hematoxylin and eosin stain, angiolymphatic and capsular invasion, accentuated mitotic activity, and positive amyloid deposits, histological findings suggestive of MTC. Immunohistochemistry confirmed the histological findings, with positive results for calcitonin, synaptophysin, and chromogranin A, and negative results for thyroglobulin. Serum calcitonin levels measured three months after surgery were $79 \mathrm{pg} / \mathrm{mL}$. One year later, laboratory follow-up showed an increase in calcitonin levels, from $79 \mathrm{pg} / \mathrm{mL}$ to $170 \mathrm{pg} / \mathrm{mL}$. The patient was then referred to our Institution.

Cervical US revealed abnormally enlarged lymph nodes, and the patient underwent a radical cervical neck dissection in an attempt to remove the persistent disease. Histopathological examination disclosed metastatic MTC in 9 of the 23 isolated lymph nodes. After three months, serum calcitonin levels were $86 \mathrm{pg} / \mathrm{mL}$, remaining stable thereafter ( 2 years of follow-up). The patient denied any cases of thyroid cancer in the family.

$R E T$ molecular analysis, performed by restriction enzyme digestion, comprising the most commonly affected codons $(609,611,618,620,630,634,768$, 804,883 , and 918) did not identified any mutations, and the patient was assumed to have a sMTC.

However, few months later, during a follow-up visit, the patient mentioned that his sister ( 57 years old) had a thyroid nodule, diagnosed as a follicular adenoma. This fact called our attention, and we requested further analysis of the tumor specimen to exclude any possibility of missing MTC diagnosis. Histopathological re-examination of the tumor followed by immunohistochemistry of the sister's paraffin block revealed a rare case of follicular variant of medullary thyroid carcinoma.

We then decided to conduct an extensive molecular analysis by direct sequencing to include all previously described RET mutations (exons 5, 8, 10-16). We identified a missense mutation in exon 15 , codon 891 
(TCG $\rightarrow$ GCG), causing a substitution of the amino acid serine for alanine (p.Ser891Ala). Molecular analysis of the patient's sister revealed the same mutation, thus confirming hereditary MTC. Genetic testing was offered for all at-risk family members. Seven carriers were identified and referred to treatment (Figure 1). Five individuals $(52,21,27,28$, and 30 years old) underwent total thyroidectomy, and MTC was diagnosed in four of them. The remaining two patients are still awaiting surgery. Screening for PHEO and HPT were negative in the patient and in all positive family members.

\section{Genetic screening}

Genomic DNA was prepared from peripheral blood leukocytes by standard procedures, and RET mutations were screened by restriction enzyme digestion and/or direct sequencing as previously described (11). Briefly, oligonucleotide primers for amplification of different $R E T$ exons were designed on the intronic sequences flanking exons 10, 11, 13, 14, 15, and 16 (11). PCRs were run in a final volume of $50 \mu \mathrm{L}$ using 100 genomic DNA, containing $20 \mathrm{mM}$ Tris $\mathrm{HCl}(\mathrm{pH} 8.4), 50$ $\mathrm{mM} \mathrm{KCl}, 1.5 \mathrm{mM} \mathrm{MgCl} 2,0.2 \mathrm{mM}$ deoxynucleotide triphosphate, $1 \mathrm{U}$ Taq polymerase, and $1 \mu \mathrm{M}$ of the specific primer. Genomic DNA was denatured for $3 \mathrm{~min}$ at $94^{\circ} \mathrm{C}$ before 35 cycles at 94,65 , and $72^{\circ} \mathrm{C}$ for $1 \mathrm{~min}$ at each temperature, followed by a 5 - $\mathrm{min}$ $72^{\circ} \mathrm{C}$ step in a programmable thermal controller (MJ Research, Inc., Waltham, MA). Following PCR, the amplicon sizes were analyzed in $1.5 \%$ agarose gel, and the products visualized by ethidium bromide staining. Whenever necessary, the presence of mutations was confirmed by direct sequencing. PCR products were

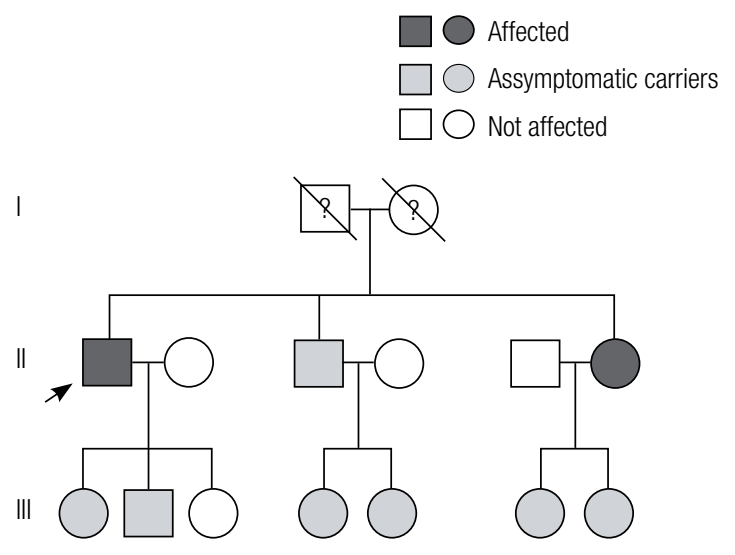

Figure 1. Pedigree of the kindred with RET germline p.Ser891Ala mutation. The arrow indicates the index cases. Screening for PHEO and HPT were negative in all gene carriers. purified using the GFX PCR DNA purification kit (GE Healthcare, Buckinghamshire, UK), and submitted to direct sequencing using the Big Dye Terminator Cycle Sequencing Ready Reaction kit (Applied Biosystems, Foster City, CA, USA) as previously described (12).

\section{Laboratory investigation}

Evaluation and follow-up of patients with MTC at our center comprises complete clinical examination, laboratory tests (levels of basal calcitonin - VR male: 12.0 $\mathrm{pg} / \mathrm{mL}$ and female: $6.0 \mathrm{pg} / \mathrm{mL}$ ), plasma parathyroid hormone (PTH; Immulite 2000 Intact PTH, Diagnostic Products), urinary fractionated metanephrines (HPLC), and, whenever indicated, diagnostic imaging investigation (cervical ultrasonography, thorax and abdominal CT). Selected patients are submitted to wholebody metaiodobenzylguanidine scintigraphy to rule out PHEO and/or distant metastases.

\section{DISCUSSION}

Molecular analysis of the RET gene is now considered the state of care in the management of MTC. It allows identification of disease carriers, as well as hereditary cases in an apparently sMTC. We report here a case of a patient presenting clinical and anatomopathological findings suggestive of sporadic disease, in whom standard molecular screening failed to identify RET mutations. Later diagnosis of a thyroid adenoma in a first-degree relative prompted us to extend molecular analysis, which identified the rare p.Ser891Ala mutation.

The RET proto-oncogene is expressed in cells of neuronal and neuroepithelial origin, and encodes a tyrosine kinase receptor $(2,13)$. Gain-of-function mutations are responsible for a permanent triggering process, and are associated with human cancers (14). Extracellular mutations in codons 609-634 affect cysteine codons, whereas intracellular mutations disrupt the tyrosine kinase domain of the receptor (15). These changes results in monomeric oncoproteins, altering both the catalytic activity and substrate specificity of the receptor due to structural changes of the binding pocket of the tyrosine kinase domain (16). Lesser constitutive RET kinase activation results in lesser transforming capacity (17).

In the vast majority of cases, MEN $2 \mathrm{~A}$ is caused by mutations affecting cysteine residues in codons 609, 611,618 , and 620 (exon 10), and codon 634 (exon 
11) of the RET gene. In FMTC, approximately 86$88 \%$ of families have mutations in one of the 5 cysteines in the extracellular domain of the RET gene in exons 10 (codons 609, 611, 618, 620), and exon 11 (codon 634) $(15,18)$. Substitutions in the intracellular domain of $R E T$ in exon 13 (codon 768, 790, 791), in exon 14 (codon 804 and 844), and in exon 15 (codon 891 ) are less frequent. Based on genotype-phenotype correlation studies, the American Thyroid Association (ATA) classifies the different mutations into four risk categories according to the aggressiveness of the disease $(\mathrm{A}<\mathrm{B}<\mathrm{C}<\mathrm{D})(8)$. This classification helps on defying the age of prophylactic thyroidectomy in asymptomatic RET mutation carriers.

The codon 891 mutation is located in the second intracellular tyrosine kinase domain (TK2) of the RET proto-oncogene and accounts for less then $5 \%$ of all germline mutations (Figure 2). Different nucleotide changes have been reported (TCG $\rightarrow$ GCG, TCG $\rightarrow$ GCT, TCG $\rightarrow$ GCC, TCG $\rightarrow$ GCA), all resulting in a serineto-alanine change. This change was described in 2.1\% of German and $4.8 \%$ of Continental European RET families. On the other hand, Romei and cols. observed a higher prevalence $(9.3 \%)$ in Italian families $(9,19,20)$. S981A belongs to those RET mutations with lowrisk transforming activity, classified as A ATA risk level (8). Although this mutation has been associated with FMTC, rare cases of PHEO ( 3.5\%) have been reported. Interestingly, no confirmed case of $\mathrm{PTH}$ was identified (Table 1). However, parathyroid hyperplasia

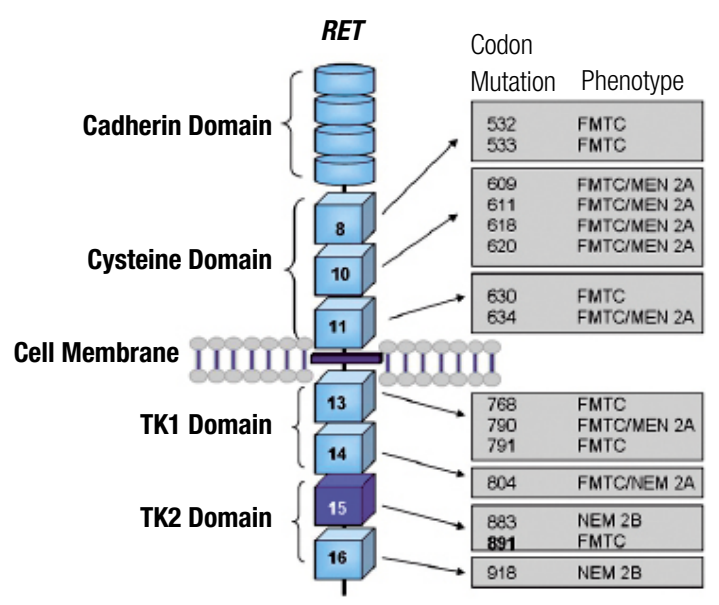

Figure 2. Schematic representation of the RET receptor. The extracellular region comprises the cadherin- and cysteine-rich domain. Two tyrosine kinase domains (TK1 and TK2) are located in the intracellular region. The corresponding exons coding for the cysteine and tyrosine kinase domains, as well as the NEM 2-associated mutations, are indicated. without evidence of clinical hyperparathyroidism has been described in three individuals of the same kindred (21). Our Division is a reference center for genetic screening of RET mutations in Brazil. Twenty-two of the 32 independent hereditary MTC kindred identified were classified as MEN 2A, and 634 mutations are found in $\sim 70 \%$ of cases. This was the first kindred harboring the p.Ser891Ala mutation identified.

This interesting case highlights the importance of proper clinical and molecular diagnostic approach in MTC patients. Since the patient presented several characteristics of sporadic disease (no other cases of thyroid cancer in the family, > 50 years at diagnosis, unilateral and unicentric MTC, and absence of either C-cell hyperplasia or other MEN2-associated neoplasm), the initial negative molecular screening enclosing the most common RET mutations was somehow expected. The assessment of the patient's family history was crucial for the hypothesis of inherited disease, as well as for the decision to perform direct sequencing of all RET gene mutations so far described. The case raises the question about the extent of molecular analysis needed to increase detection of familial medullary thyroid cancer in apparently sporadic cases. While the screening of all known mutation loci is recommended by some authors, the costs of a full analysis should be also taken into consideration (22). A new approach, influenced by age at diagnosis and probability of familial disease has been proposed, including exons 10 and 11 in routine screening. The authors suggest extending genetic analysis for those under 45 years of age at diagnosis, and in whom clinical data show increased probability of inherited disease (10). Given the high prevalence of mutations found in non-cysteine codons in apparently sMTC, Romei and cols. recommend that RET genetic screening should also cover exons 5,8,13,14, and 15 (23). More recently, Lindsey and cols. have suggested screening of hotspot exons in a first analysis, followed by the remaining $R E T$ regions, if the hotspots are negative (24).

Although controversial, we believe that standard molecular screening is adequate for most cases of MTC. It appears that there is no direct clinical benefit in extending RET germline analysis beyond the hotspot regions in sMTC (24). However, one should keep in mind that a meticulous family history and close follow-up are mandatory. Any clinical or familial aspect that might suggest inherited disease should prompt additional analysis. 
Table 1. Clinical presentation in 85 patients positive for RET p.Ser891Ala mutation

\begin{tabular}{|c|c|c|c|c|c|c|c|c|}
\hline $\mathrm{N}^{0}$ patients & $\begin{array}{l}\mathrm{N}^{0} \text { affected } \\
\text { patients }\end{array}$ & $\begin{array}{l}\text { Asymptomatic } \\
\text { gene carriers }\end{array}$ & $\begin{array}{l}\text { Mean age of } \\
\text { MTC diagnosis }\end{array}$ & MTC & PHEO & $\begin{array}{l}\text { Lymph node } \\
\text { metastasis }\end{array}$ & $\begin{array}{c}\text { Distant } \\
\text { metastasis }\end{array}$ & Reference \\
\hline 9 & $6(66.7 \%)$ & $1(11.1 \%)^{*}$ & 39.7 & $6(66.7 \%)$ & 0 & $2(22.2 \%)$ & No & Blom and cols. \\
\hline 36 & 33 (92\%) & $3(8 \%)$ & 41 & $25(86 \%)$ & $1(3 \%)$ & $19(53 \%)$ & No & Schulte and cols. \\
\hline 6 & $3(50 \%)$ & $3(50 \%)$ & 45 & $2(67 \%)$ & $1(17 \%)$ & $1(17 \%)$ & Yes & Jimenez and cols. \\
\hline 5 & $3(60 \%)$ & $2(40 \%)$ & 47 & 3 (100\%) & 0 & ND & No & Hofstra and cols. \\
\hline 3 & $3(100 \%)$ & 0 & ND & $3(100 \%)$ & ND & ND & ND & Dang and cols. \\
\hline 14 & $6(43 \%)$ & $8(57 \%)$ & 44 & $6(100 \%)$ & ND & ND & ND & Elisei and cols. \\
\hline 3 & $3(100 \%)$ & 0 & ND & $3(100 \%)$ & 0 & $N D$ & Yes & Yip and cols. \\
\hline 1 & $1(100 \%)$ & 0 & ND & $1(100 \%)$ & $1(100 \%)$ & ND & ND & Asari and cols. \\
\hline 2 & $2(100 \%)$ & 0 & ND & $2(100 \%)$ & 0 & $2(100 \%)$ & No & Paszko and cols. \\
\hline 4 & $2(50 \%)$ & $2(50 \%)$ & 49 & $2(50 \%)$ & 0 & ND & No & Wohllk and cols. \\
\hline 85 & 62 (72.9\%) & $17(20 \%)$ & 42.3 & $53(62.3 \%)$ & $3(3.5 \%)$ & 24 (28.2\%) & $2(2.3 \%)$ & Total \\
\hline
\end{tabular}

Table adapted from ref. 21. * Two patients are still awaiting surgery.

Acknowledgements: we would like to thank Conselho Nacional de Desenvolvimento Científico e Tecnológico (CNPq), Fundação de Amparo à Pesquisa do Estado do Rio Grande do Sul (Fapergs), Fundo de Incentivo à Pesquisa (Fipe), and Programa de Apoio a Núcleos de Excelência (Pronex), Brazil.

Financial support: Conselho Nacional de Desenvolvimento Científico e Tecnológico (CNPq), and Fundo de Incentivo à Pesquisa (Fipe), Brazil.

Disclosure: no potential conflict of interest relevant to this article was reported.

\section{REFERENCES}

1. Hundal SA, Fleming ID, Fremgen AM, Menck HR. A National Cancer Data Base Report n 53,856 cases of thyroid carcinoma treated in the U.S., 1985-1995. Cancer. 1998;15;83(12):2638-48.

2. Ceolin L, Siqueira DR, Romitti M, Ferreira CV, Maia AL. Molecular Basis of Medullary Thyroid Carcinoma: the role of RET polymorphisms. Int J Mol Sci. 2012;13(1):221-39.

3. Mulligan LM, Kwok JB, Healey CS, Elsdon MJ, Eng C, Gardner E, et al. Germline mutations of the RET proto-oncogene in multiple endocrine neoplasia type 2A. Nature. 1993;363(6428):458-60.

4. Machens A, Gimm O, Hinze R, Hoppner W, Boehm BO, Dralle H. Genotype-phenotype correlations in hereditary medullary thyroid carcinoma: oncological features and biochemical properties. J Clin Endocrinol Metab. 2001;86(3):1104-9.

5. Moley JF, DeBenedetti MK. Patterns of nodal metastasis in palpable medullary thyroid carcinoma: recomendations for extent of node dissection. Ann Surg. 1999;229(6):880-7.

6. Puñales MK, da Rocha AP, Meotti C, Gross JL, Maia AL. Clinical and oncological features of children and young adults with multiple endocrine neoplasia type 2. Thyroid. 2008;18(12):1261-8.

7. Maia AL, Puñales MK, Mazeto G, Caldas G, Ward LS, Kimura ET, et al. Diretrizes clínicas na saúde suplementar - Câncer Medular deTireoide: Diagnóstico. Associação Médica Brasileira e Agência Nacional de Saúde Suplementar. 2011;15:1-23.

8. American Thyroid Association Guidelines Task Force, Kloos RT, Eng C, Evans DB, Francis GL, Gagel RF, et al. Medullary thyroid cancer: management guidelines of the American Thyroid Association. Thyroid. 2009;19(6):565-612. Review. Erratum in: Thyroid. 2009;19(11):1295.

9. Romei C, Mariotti S, Fugazzola L, Taccaliti A, Pacini F, Opocher $\mathrm{G}$, et al. Multiple endocrine neoplasia type 2 syndromes (MEN 2): results from the ItaMEN network analysis on the prevalence of different genotypes and phenotypes. Eur J Endocrinol. 2010;163(2):301-8.

10. Wiench M, Wygoda Z, Gubala E, Wloch J, Lisowska K, Krassowski $\mathrm{J}$, et al. Estimation of risk of inherited medullary thyroid carcinoma in apparent sporadic patients. J Clin Oncol. 2001;19(5):1374-80.

11. Punales MK, Graf H, Gross JL, Maia AL. RET codon 634 mutations in multiple endocrine neoplasia type 2: variable clinical features and clinical outcome. J Clin Endocrinol Metab. 2003;88(6):2644-9.

12. Siqueira DR, Romitti M, da Rocha AP, Ceolin L, Meotti C, Estivalet A, et al. The RET polymorphic allele S836S is associated with early metastatic disease in patients with hereditary or sporadic medullary thyroid carcinoma. Endocr Relat Cancer. 2010;17(4):953-63.

13. Takahashi $M$, Buma $Y$, Iwamoto $T$, Inaguma $Y$, Ikeda $H$, Hiai $H$. Cloning and expression of the RET proto-oncogene encoding a tyrosine-kinase with two potential transmembrane domain. Oncogene. 1988;3(5):571-8.

14. Santoro M, Mellilo RM, Carlomagno F, Fusco A, Vecchio G. Molecular mechanism of RET activation in human cancer. Ann NY Acad Science. 2002;963:116-21.

15. Hofstra RM, Fattoruso O, Quadro L, Wu Y, Libroia A, Verga U, et al. A novel point mutation in the intracellular domain of the ret protooncogene in a family with medullary thyroid carcinoma. $J$ Clin Endocrinol Metab. 1997;82(12):4176-8.

16. Plaza-Menacho I, Koster R, van der Sloot AM, Quax WJ, Osinga $\mathrm{J}$, van der Sluis T, et al. RET-familial medullary thyroid carcinoma mutants Y791F and S891A activate a Src/JAK/STAT3 pathway, independent of glial cell line-derived neurotrophic factor. Cancer Res. 2005;65(5):1729-37.

17. Machens A, Dralle H. Genotype-pheotype based surgical concept of hereditary medullary thyroid carcinoma. World J Surg. 2007;31(5):957-68.

18. Mulligan LM, Eng C, Healey CS, Clayton D, Kwok JB, Gardner $\mathrm{E}$, et al. Specific mutations of the RET proto-oncogene are related to disease phenotype in MEN 2A and FMTC. Nat Genet. 1994;6(1):70-4. 
19. Machens A, Dralle H. Familial prevalence and age of RET germline mutations: implications for screening. Clin Endocrinol. 2008;69(1):81-7.

20. Machens A, Lorenz K, Dralle H. Constitutive RET tyrosine kinase activation in hereditary medullary thyroid cancer: clinical opportunities. J Intern Med. 2009;266(1):114-25.

21. Schulte KM, Machens A, Fugazzola L, McGregor A, Diaz-Cano S, Izatt $L$, et al. The clinical spectrum of multiple endocrine neoplasia type 2a caused by the rare intracellular RET mutation S891A. J Clin Endocrinol Metab. 2010;95(9):E92-7.
22. Eng C. RET proto-oncogene in the development of human cancer. J Clin Oncol. 1999;7(1):380-93.

23. Romei C, Cosci B, Renzini G, Bottici V, Molinaro E, Agate L, et al. RET genetic screening of sporadic medullary thyroid cancer (MTC) allows the preclinical diagnosis of unsuspected gene carriers and the identification of a relevant percentage of hidden familial MTC (FMTC). Clin Endocrinol. 2011;74(2):241-7.

24. Lindsey SC, Kunii IS, Germano-Neto F, Sittoni MY, Camacho CP, Valente FO, et al. Extended RET gene analysis in patients with apparently sporadic medullary thyroid cancer: clinical benefits and cost. Horm Cancer. 2012;3(4):181-6. 